\title{
BUT FOR THE APOCALYPSE: WILFRIDO NOLLEDO'S DARK MIRROR OF EMPIRE
}

\author{
Ryan Canlas \\ Art Institute of Las Vegas \\ racan1978@gmail.com
}

\begin{abstract}
This essay reads Wilfrido Nolledo's novel, But for the Lovers (1970), across the rocky terrain in which the postcolonial Anglophone novel intersects with the question of postmodernity. Using Paul Ricoeur's Memory, History, and Forgetting and Fredric Jameson's exhortation to the critic to "Always historicize!" as my primary theoretical frameworks, I argue against the seemingly common accusation that the "postmodern" Anglophone Filipino novel--of which But for the Lovers is a kind of prototypical example--is incapable of creating a perspective on the political and historical conditions of the Philippines as a postcolonial nation and that it is merely symptomatic of the much larger political, social, and cultural malaise characteristic of the current political economic and cultural moment. My argument is that But for the Lovers forces the critic to resituate her perspective on the problems of Philippine nationalism by linking it to the question of the novel's style: only by doing so can the way that history and fiction narrate and produce knowledge about the past be interrogated. Ultimately, I argue that But for the Lovers demonstrates that the ultimate horizon for any reading of Anglophone Philippine fiction is not just history, but the unassailable historical condition of US imperialism in the Philippines. The novel's apocalyptic finale, I suggest, dramatizes the large-scale violence and genocide that founds, as historian Dylan Rodriguez argues, the moment of US-Philippine "contact" in the early twentieth century, and in this way conditions the very possibility of a Filipino literature in English.
\end{abstract}

\section{Keywords}

Filipino Novels in English, Postmodernity, Postcoloniality, Genocide, Historiography, World War II, Manifest Destiny, Philippine American War, Filipino Novels in English 


\section{About the Author}

Ryan Canlas received his $\mathrm{PhD}$ in English from Cornell University. He has been published in positions: East Asia Critique and has a forthcoming essay in Novel: A Forum on Fiction. His areas of research include twentieth century literature, African American, American Indian, Chicano/ Latino, and Asian American literature, literary theory, anti-colonial thought, twentieth century critical theory and philosophy, and Marxism. His current project looks at ways of developing a literary hermeneutic devoted to understanding the kinds of knowledge producible in the intersections between literature and history, reading the literature of U.S. writers of color from the twin axes of America's nation-building project and its imperial expansion westward across the continent and into the Pacific. 


\section{Postmodernism, History, and Literary Style}

A rather unsavory question lies at the heart of Wilfrido Nolledo's 1970 novel, But for the Lovers: what if the United States' imperial endeavor in the Philippines were inevitable? What if its liberation of the country from the Japanese Occupation were a narrative written with the tone and language of defeat and resignation? What if, the novel seems to ask, the reader were to reluctantly accept the idea that General Douglas MacArthur's promise to return was underwritten by fate itself? How would that sit with the reader, and in what ways can the intertwined histories of the Philippines and the United States, from the Philippine-American War to the present, be rethought through a novel that advances this proposition as a function of its fictional universe? It would seem to confirm-or at the very least echo-the story of Manifest Destiny.

And yet, the United States' return also marks an ambiguous spot in the novel's symbolic and metaphorical terrain. The return can easily be allegorized through the trope of a "second coming," which, as Jaime Lim has argued, is woven throughout the novel by constant reference to William Butler Yeats's poem of the same name (245). Apropos of its biblical origin, the second coming can be seen as two things at once: the return of a savior and the unleashing of an apocalypse. The ambiguity that structures the novel's symbolic order, as it distributes the idea of the US' return across its pages, would seem to indicate the novel's inability to resolve the questions it poses for itself, if not its unwillingness to do so. Part of this ambiguity lies in the novel's immensely complex and allusive style. But for the Lovers, and its large ensemble of characters (from the operator of a strip club and its customers, to the proprietress of an apartment building and its many tenants, to Filipino guerillas and their supporters, to kempeitai to US airmen), focuses on the last few months of the Second World War, at a time when the Japanese were scrambling to keep what shred of power they had in the Philippines as rumors and promises of America's return were gaining strength; written in a highly complex and baroque language, the perspective shifts focus from one character to the next, the reader being led through the terrain of Manila and the mountains of Luzon while receiving conflicting viewpoints on the war's end and in the significance that it would have for the Philippines-what would its future look like, and who would be directing it? On this point, Lim has suggested that But for the Lovers, with its multitude of voices and styles, carries its many questions about Philippine history to a dead end, that its dense linguistic and stylistic weave blocks any light that may come from an answer on the other side of its language and opts instead to remain content to pose the riddle-and to leave it at that-of the Philippines' future as a truly sovereign nation that has finally broken its ties to the United States and its imperial legacy (Lim 258). In this view, the novel itself may be the final apotheosis of the many Sphinx-like figures that appear throughout the course of its narrative,

Kritika Kultura 24 (2015): -178

(C) Ateneo de Manila University

<http://kritikakultura.ateneo.net> 
ciphers in which some secret about Philippine freedom may be housed but which the novel offers no keys to unlocking.

This interpretation is certainly valid; it is, however, incomplete. What occurs in the novel's epilogue undercuts whatever ambiguity the novel creates around the question of the Philippines' past, present, and future. One of the characters who shows up intermittently throughout the novel-a schoolteacher named Placido Rey-is revealed to be the writer of everything leading up to the epilogue, all of which has been composed as a series of "Dickensian notes . . crammed with objectivity and ornate vernacular" (Nolledo 315). Rey's decision to cull these notes together is prompted by his desire to shield the waif-like Alma from the world that has come upon him: the Americans have indeed returned to the Philippines, the Second World War is over, and Rey has been consigned to teaching on an Army base in an undisclosed location in the country. Alma, throughout the novel, has been the object of desire by many: there is Major Shigura, who follows her around Manila on his white horse; there is Spaniard Hidalgo, a washed-up vaudevillian clown who dreams of a Spanish renaissance and who educates Alma in all things Iberian; and there is Jonas Winters, an American pilot shot down by the Japanese and who falls into a fever after receiving a kiss from her as he is being paraded on a stretcher. Alma is an entirely nebulous figure, and one can easily see her as a symbol of the Philippines itself: undefined and indefinable, a place that three empires-the Spanish, the American, and the Japanese-have clamored over during the course of five centuries. It could be, then, that Rey's desire to protect her in the aftermath of the war is a way of allegorizing the writer's need to write in order to preserve a modicum of freedom in and against a brutal world. The critic can appeal, for instance, to something like Theodor Adorno's negative dialectic in order to support such a reading. In this case literature's autonomy could be seen as wresting from the imagination its independence from the circuits of accumulation and exchange, accomplished, for Adorno, by the challenges posed by an abstruse aesthetic form (255). The critic may also look to Jacques Ranciére, and argue that literature engages the reader's imagination by its "redistribution of the sensible," guiding the reader's thoughts in this way to an alternative vision of how society and political allegiances can be composed (13-15). Read through either philosopher, the narrative's density and its ornateness could be seen as a way of safeguarding literature's autonomy, of isolating what Rey has written from the world in order that it may critique this world more effectively, the narrative's complexity producing between the reader and text a kind of interaction through which the political becomes clarified within the sovereign space of literature. The epilogue alone may be allegorizing the power of the imagination in constructing a space in which the figure of a Philippines beset by multiple empires can be withheld linguistically and imaginatively from its conquerors, thereby turning the novel's reticence on the historical problems of the Philippines into a strategy that allows the political ethos specific to literature to arise: that of presenting concepts and images by which the reader can reflect 
on this history and its relationship to the United States rather than advancing a solution to it.

But Rey's epilogue is less a celebration of the power of literature than an admission of its tenuous hold over an imagination that can only function as a "seclusion" from the world and its "blandishments," which Rey ends up repulsing (Nolledo 314) - the imagination here is the source of an "ache" for Alma that he can both nurture and attempt to quell through his writing (311). In the epilogue, one senses that the reality of the American return can only elicit a response where the imagination failingly tries to ward off the real, the concrete, and the historical; after all, the entire narrative has served as an ornate attempt to protect Alma by writing her into a complex web of stories that, in the end, perpetuates the destruction of every major character except Alma and her semi-disfigured companion, the guitarist Amoran, who stands in as a kind of figure of "the people," a quasi-populist symbol of the common and its endurance in the face of destruction (Teodoro 21). This destruction is Rey's "blasphemy," as he calls it-but against what? Against, perhaps, the hallowed return of the Christ-like America? Maybe. Rey remains reticent, and Nolledo provides no clues as to what exactly being blasphemous means except that it involves withholding Alma's name from the post-war world of the Philippines, and that it involves Rey having to write stories and wrap Alma inside endless and looping lines of verbiage in order to ensure that "[n] either a Hidalgo nor a Shigura," nor any American solider, "would leave one mark on her" (Nolledo 315). If there is hope at the end of But for the Lovers, it is undermined by the aura of fate with which the narrative surrounds the American return. And if the entirety of the novel up to the epilogue was Rey's attempt to leave in suspension the question of who would possess Alma and for whom, moreover, "she would exist" (315) - which in turn suspends the very future of Philippine nationalism and for and by whom it would be established-the passage from the fictional realm of the narrative to the reality that Rey faces leaves the reader with the sense that the American return is something against which Rey will failingly fight against as he writes (315). The novel seems to be saying that all writing can do is retreat; Rey ends up recoiling from the brute facts of the historical situation that he can no more militate against than any of the other characters he has killed off.

The autonomy of literature and the sovereignty of the imagination, it appears, has come home to roost; reality is always there, and will always be there, to remind the writer and the reader that even the most complex narratives must end and that when they do, whatever suspension of the banalities and cruelties of the world they have affected will dissolve and the brutality of all existence beyond the aesthetic will rear its ugly head once again. Is this not exactly the kind of criticism of "postmodern" Filipino writing in English that Jessica Hagedorn and, most recently, Miguel Syjuco have elicited?' ${ }^{1}$ The argument is that these novels abandon whatever hardcore politics that a more realist approach would proffer, and it is not without an obvious sense of the dislocation between the Philippines and the Philippine 
diaspora that such criticisms are made; the objects of such attacks, after all, are Filipinos not living and working in the Philippines. This kind of reasoning says that the formal play that the postmodern moment has unleashed and continues to perpetuate in the aesthetic realm replaces whatever political engagement these Filipino writers could potentially introduce into their novels with stylistic wildness and excess, a linguistic chaos that on the surface seems to subvert order and homogeneity but in reality serves a publishing industry eager to capitalize on Western readers' supposed hunger for challenging work that is at best nominal in its disruptiveness and at worst an emblem of a global hierarchization of literary discourse. As E. San Juan, Jr. argues, this is an industry that sells subversion only under the condition that resistance remain on the level of style, a style that, in the end, sells ("Filipino Writing in the United States" 158). Could But for the Lovers merely be allegorizing, avant la lettre, such an attack on the postmodern Filipino novel? Could its lesson in the end be intertwined with the performance of precisely the dialectic between literary style, politics, and the historical conjuncture labeled as postmodernism? Perhaps.

Criticisms like this revolve around a theme common to theories of postmodernity, theories who fundamental precepts But for the Lovers seems to have anticipated: namely, that the nation-state is, at worst, an illegitimate political and cultural formation or, at best, a secondary player to the much larger global and cosmopolitan transformations in political economies and cultures, themes and tropes that postmodernist novels either employ or inadvertently recapitulate. The growing contradictions between a global market and the increasingly deregulated flow of capital and goods across national borders, and the legal and political implications of the state's transformed role as both manager and executor of laws, as well as provider and recipient of the labor required to keep up this dialectic, is, as David Harvey reminds us, characteristic of the transformations in capitalism over the last thirty years. ${ }^{2}$ In terms of the present essay, the problem is this: that if an Anglophone Filipino writer caters primarily to a cosmopolitan crowd, then the problems specific to the Philippines are buried by a set of stylistic choices meant to only superficially draw the readers' attention to the country's many ills, key among them being the Philippines' continued ideological, political, and economic dependence upon the United States and upon global capitalism, to which it, like many so-called postcolonial countries, remains merely an appendage.

This links up with other, broader issues of postmodernity, as described by a number of its key theorists. Jean-Francois Lyotard argued that postmodernity is characterized by the ever-increasing spread of the logic of the language game in key areas of life, and that this turns modern cultural, political, and economic existence into the administration of rules and regulations whose criteria can no longer appeal for legitimacy to any principle external to the "speech acts" that comprise them (9-23). Fredric Jameson, in a similar way, understood postmodernity as a late capitalist formation in which the prevailing practice is dominated by the 
spectacularization of styles and histories to the point where "the simulacrum" has replaced any concrete notion of historical time as a continuum (18), while Jürgen Habermas laments postmodernity's corruption, at the hands of its chief cultural practitioners, of modernity's rational ideal, which required the aesthetic realm to remain autonomous, as prescribed by Enlightenment principles, so as to provide ample space for critical reflection and cultural production (8-11). In the context of literary studies, what is at stake here in these and in the kinds of arguments made by San Juan, certainly one of the more vocal antagonists of postmodern Filipino writing, are the disjunctions that postmodernity has signaled and continues to produce between the possibility of actual political and social transformation and the kinds of literary work currently holding sway in academies and in the Western literary marketplace; this kind of literature, the argument goes, is characterized by a political malaise that masquerades itself with an exuberance of style, one that celebrates the apparent impossibility of building or rebuilding an historical imagination shaped by a materialist understanding of the dialectics between politics, culture, and history ("Filipino Writing in the United States" 158). For San Juan, the issue is the individual author's creative, intellectual, and political acumen, one that were it to reach proper maturity would make it possible for her to represent Philippine history, an ability that then doubles over into an accurate rendering of the present and all of its contradictions.

If the accusation against so-called postmodern texts written by Filipinos in the U.S. is that they cannot account for the Philippines's passage from the past to the present, then the argument is also that they are incapable of positing a redemptive future. The stylistic carnival that is the postmodern text turns out to revel in nothing but its own linguistic bravura. Whatever politics the novel can be said to embody, express, convey, represent, or advance becomes muddled in the novelist's affair with multiplicity and with the spectacle and phantasmagoria of Philippineand sometimes even American-life, with the following consequence: whatever clear line between past, present, and future can be said to exist is concealed or perhaps even squeezed out by the sense of multiplicity that the Philippines and the Philippine diaspora are marked by, excesses that merely redouble in literary form the social and political chaos, not to mention the excesses of consumerism, that plague the global political economy and set countries like the Philippines back from achieving political and economic independence and sovereignty. San Juan's criticism, for instance, of the style stereotypical of postmodernism proceeds by distinguishing it from other, earlier kinds of writing, his main protagonist in this fight being Carlos Bulosan, whose presentation of a "concrete universal" project is based upon a materialist understanding of the intertwined histories of the Philippines and the United States. ${ }^{3}$ The implication here is that these kinds of distinctions between literary style can be made according to the supposed political logics particular to each, distinctions that turn out to revolve around the critic's 
assumption that postmodernist writing is incapable of envisioning a nationalist project.

San Juan's criticism of postmodernist writing is unacceptable, however, if we remind ourselves of Fredric Jameson's argument that the horizon for any historical materialist interpretation of literary style is contingent upon the critic's ability to develop a hermeneutic that exposes the way the novel's form is nothing more-but also nothing less - than an accretion of both literary and historical contradictions, that literary style is a failed resolution of any given set of ideological problems with both literary and non-literary import (the ideology of selfhood and subjectivity that arose during the late nineteenth century, anxieties about the changing terms of skill and production and craft during the Industrial Revolution, the relationship between art and commerce, the shifting modes of collective labor and the reorganization of social and political life required by new forms of capital, etc.) ${ }^{4}$. Seen in this light, San Juan's criticism confuses what the critic says the novel can do and what the critique assumes the novel is capable of doing independently of the hermeneutic the critic employs. It is to confuse the question of literary style as being in itself a stumbling block for social and political critique, whereas the opposite is the case. The question the critic should ask of the postmodern Filipino novel in English, then, should be what kind of a hermeneutic is capable of determining its political value at the present conjuncture, and what its failures have to say about the relationship between the history of the Philippines and the form specific to a novel like But for the Lovers. This question, moreover, dovetails into another: what kind of an epistemology of Philippine history, and the three empires from which it is inseparable, can such a literary hermeneutic help shape? San Juan's criticism inadvertently introduces an unbridgeable distance between the literary critic and scholar and the literary work, treating the novel in question as entirely independent of the kind of political work the critic imputes to it. The novel then becomes a positivist object of study; it turns into a mere reflection of late capitalism and neoliberalism, with the consequence that the work itself is vilified in one fell swoop along with the latter, with no reflection on the critical apparatus at work in making such a distinction between postmodernist texts and its "others" possible in the first place.

Returning to Lim's argument, if indeed But for the Lovers does not pose any answers to its riddles about the Philippines' history and the various empires that have occupied it - the United States, Spain, and Japan — and that it cannot as such pose even rudimentary solutions to the problem of the country's future in the age of globalization, it is also possible to say that the question that drives Lim to make such a claim is off the mark. It assumes a direct homology between the imaginative, cultural, and intellectual work done by and through the novel with the kind of work conceivable and doable in the political realm. There is no attempt here to establish a hermeneutic capable of interrogating the complex relationship between literature, politics, and criticism. 
This is not, however, to defend outright the postmodernist Filipino novel in English. The claims about what is postmodern, and what it has to do with the politics and history of the Philippines and its relationship to the United States, are what interest me. How it pertains to the way that But for the Lovers makes it possible to reread the dynamics between them is of critical importance because it may allow the critic and scholar to rethink what it means to claim that literature can say something political about the past, the present, and the future, and what these temporal and historical categories have to say about the relationship between the Philippines and the Philippine diaspora. For if one of the accusations against postmodernist Filipino novels in English is that they indulge the appetites of a Western audience, then such blame is being made blatantly along an antagonism drawn between not only a hardcore nationalist politics and a facile cosmopolitanism, but between substance and style as well. Caroline Hau has argued as much: "there is a tendency among some Philippinists to theorize the 'content' of Philippine literature in terms of an antithesis/synthesis of, on the one hand, the preoccupation with the craft of writing, and, on the other hand, the preoccupation with realist depictions of Philippine society and with propounding political solutions" (272). Such an antagonism buries the question of whether or not difficult literature, one that is concerned with the "craft of writing," is a marker of the literary imagination's autonomy with respect to the political and historical. If so, when you have a novel as challenging as But for the Lovers, does this autonomy not merely confirm suspicions against works such as these by directing itself only to a handful of "experts" and "professional readers" in the Western academy or to the taste-makers among the literati?

That is one way of seeing things. But it seems more productive to think of the novel's place in the dynamic I have elaborated above in the following terms: when But for the Lovers' style comes into play, the question has to do with the way the novel makes it possible to think of Filipino literature in English politically in the present day, a politics that is a function of the novel's style, a style seen as having something to do-either as a response to or a recapitulation of-the historical moment of postmodernism and its attendant political, cultural, and economic contradictions. How does one read the novel in light of the transition, rupture, or continuity between both the political economic and the cultural moments of modernity and postmodernity, and what kind of an epistemology is possible when rereading this historical narrative through the lens of America's imperial project in the Philippines from the Second World War on? The voice that anchors the novel's motley idioms and styles is one that turns the text into an investigation of the past treated not as the storehouse for reading the present or the future, but rather as a thing to be remade, mythicized, and turned explicitly into a fiction so as to ground all the more the reality whose ultimate riddle the reader is meant to confront and perhaps be confounded by. And it does this by stylistically radicalizing the wildness of postmodernity's heterogeneous and rather insouciant regard for 
history and metanarratives while also enjoining it to the often formally disruptive and occasionally bleak myth-making ambitions characteristic of much of high modernism, from Baudelaire to Rimbaud to Eliot to Joyce to Lowry to Faulkner to Toomer and to Césaire.

The tension that Nolledo's novel sets to work is that between the narrative of continuity that modernism unleashed as a way of investigating and even restoring the social, cultural, and political dissolutions of the West, and the discontinuities that the postmodern age has privileged as a response to such dissolutions. It is here where a study in full of the implications of But for the Lovers' stylistic features can properly begin: with the question of colonialism and empire. The disintegration of western European hegemony across the twentieth century-from the rise of communism in eastern Europe to the massive destruction wrought by the First and Second World Wars, to the anti-colonial revolts in much of the former colonies of North Africa, Southeast Asia, South Asia, the Caribbean, and Latin Americagave way to alternative models of organization and thought that looked, variously, to the excessive, the subaltern, the heterogeneous, the marginalized, and the victim. These are narratives that, in the Philippine case, have been both disruptive of the dominant histories of Spanish and American imperialism by rewriting history from below while also establishing some semblance of historical continuity, reoriented through the perspective of political, economic, and cultural resistance. Teodoro Agoncillo's The Revolt of the Masses, Renato Constantino's The Philippines: A Past Revisited, Amado Guerrero's Philippine Society and Revolution, and Reynaldo Ileto's Pasyon and Revolution all, in their own ways, provide a kind of substratum for a historiography of Philippine political ontologies. In so doing they also establish an epistemological framework by which to reread Philippine history as a history of failed revolutions, a perspective that is disruptive to the core and suspicious of the grand narrative of capital and empire and yet unwilling to dispense with the notion that history can indeed be driven by a communicable and representable logic.

This is why But for the Lovers presents such a troubling-and important-case for thinking of the ways that literature fits into this problem of writing history as a political act. The novel employs its radical aesthetic, which can be seen as a combination of both high modernism and postmodernism, in order to trouble the historical, cultural, and political distinctions imputed to each. In so doing it throws back at the reader's faces the very problem of the US' return by posing this question: what if empire was and is inevitable? How then do we read Philippine and American history-and by extension a whole set of relations describable through the condition called postmodernity and under the aegis of globalization? Is the only solution, as Nolledo's novel provokes the reader into asking, to opt for an apocalypse where everything about the world that has resulted in such a poor version of one's dreams-in which the American return could not have been otherwise-must be destroyed in one ruthless act of the imagination?

Kritika Kultura 24 (2015): -178 


\section{Allegorizing Genocide: Towards a Literary Hermeneutic}

It is crucial that Placido Rey represents himself as a sympathizer and affiliate of the Filipino guerilla leader Deogracias, whose aim is to spread the rumor and to foment the idea that the Philippines' liberation is at hand. In one of the more lengthy scenes that features Rey, he is shown reading The Manila Times, which carries news and a photo (propaganda advanced by the Japanese authorities) of the shooting down of an American P-38 during a dogfight with the Japanese, a battle witnessed by many of the novel's characters from their standpoints on rooftops or on the beach overlooking Manila Bay. The intention of the article is to dissuade its readers from believing that salvation, at the hand of the Americans, is near, but Rey "will not fall prey to exaggeration that easily. He will surmise, and wisely too, that this is an isolated fact." As he stares longer at the image of the shot-down P-38, he notices a white spot that the Japanese failed to completely doctor out and realizes that it is the pilot: he had ejected from the cockpit just in time. "The pilot is alive!" Rey says to himself. But he decides to keep silent about his discovery, and opts instead to "deduce," in a "partisan frame of mind," that the pilot has not been captured, and that his survival means that, upon others learning of this news, "a secret army of optimists will grow, related to but remote from Placido Rey. In like hope, in like manner, they will congeal in subversive brotherhood" (Nolledo 149-150). It is important that this part is told in the future perfect tense. It begins, “Tomorrow Placido Rey will hold The Manila Tribune" (148) and ends with another hopeful "Tomorrow" (150). The optimistic tone clashes violently with the epilogue's disillusionment. On the one hand, there is hope in the Americans, and on the other the sense that liberation was not only a failure but an utter illusion. The future perfect endows tomorrow in the scene above with a sense of certainty, in which the hope that this tomorrow brings has validity and is corroborated by the narrative's tense. Hope can thrive tomorrow only because the narration provides the foundation upon which this hope can be carried out. Once the reader arrives at the epilogue, this hope is undercut, and tomorrow begins to look like nothing more than another disappointment.

Because Rey has chosen to compile his "Dickensian notes" from a perspective beset by disillusions, the temporality that the epilogue creates is filled with tensions. The prolepsis created in the scene above is, after all, possible only because Rey is in a "partisan frame of mind." This partisanship allows him to construct the fiction that "a secret army will grow" once his deduction that the pilot is still alive becomes not only fact, but the object of a surreptitious knowledge shared only by other partisans as well. It is significant that what tomorrow brings is not the news of the pilot's survival, but Rey's belief in his survival and the subsequent fiction he concocts through this "wise" deduction. One can say here that this interjection"and wisely, too"-is Rey interrupting the scene from the standpoint of his future

Kritika Kultura 24 (2015): -178

(C) Ateneo de Manila University

<http://kritikakultura.ateneo.net> 
self: the pilot, as the reader learns, did actually survive. It is also significant, however, that Rey's interjections remain for the most part minimal: he makes no attempt to judge his misplaced hopes. This is why the revelation that Rey is the narrator is so surprising. He is virtually absent-as focalizer, as writer, as historiographer-until the end; there is no indication prior to this moment that Rey is anything but one of the many semi-marginal characters in the story. The fiction of the "secret army" is thus allowed to flourish at this point in the narrative, without interruption and commentary. He removes himself as judge of the past, and by doing so leaves the reader with a tableau whose political framework remains suspended. This is the M.O., so to speak, of the entire novel: withhold judgment so that the narrative becomes a sequence of events told with no apparent partisanship in mind. As the novel's focalizer, Rey allows whatever hopes the characters harbor (and there are many of them) to thrive. But he does not submit them to a pre-established set of hierarchies or antagonisms, an operation possible only because Rey, as narrator and writer, removes himself so effectively from the text as commentator and judge. Once the frame is revealed, however, once Rey makes his declaration of blasphemy against the Americans' presence, the reader is essentially drawn into the position of having to judge the fiction of Rey's secret army and of the American liberation's promise an utter failure. The result is that the Placido Rey of the novel's diegetic past is judged for his partisanship: the reader sees it is a misguided and foolish dream, retroactively assessed with the help of Rey himself.

The question is: what kind of a self-assessment is Rey performing, and by extension what kind of a vision of the past is he presenting to the reader? By the end of the novel, with the retrospective mode firmly in place, one could argue that Rey is perhaps judging his own past a failure, that his belief in the salvation of the Philippines was a foolhardy attempt indeed. But this introduces a problem: such an interpretation is valid only to the extent that the reader suspend her knowledge of the actual course that history has taken. This is more than a simple reenactment of a Coleridgean "willing suspension of disbelief," however; when it concerns history's place in a fictional work, it requires the reader to maintain the tension between what the fictional work makes possible as a function of the imagination (however explicitly politicized or not) and what is common knowledge. The latter therefore acts as the material horizon for any reading that assesses the fictional aspects of the work, of the distance between what the imagination produces and the concrete history that is either its foundation or source material.

This tension between the fictive world of the poetic imagination and the history that it responds to is what prompted Paul Ricoeur to argue that forgiveness is possible even as one writes a history of warfare, cruelty, and savagery. In Memory, History, and Forgetting, Ricoeur's magisterial account of the epistemology of history writing, he contends that one component required in writing of such a past involves forgiving the butchers, and that doing so means that "the guilty person is to be considered capable of something other than his offenses and his faults. He

Kritika Kultura 24 (2015): -178 
is held to be restored to his capacity for acting, and action restored to its capacity for continuing. .. [T] his restored capacity is enlisted by promising as it projects action toward the future" (493). Assessing the past, and doing so magnanimously, involves judging the guilty party while at the same time acknowledging explicitly the contingency of human action, of imagining that things could have transpired otherwise. Inscribed into the act of forgiveness is the historiographer's subtle admission, "I know, if only abstractly, that you are better than this. I can imagine that you are greater than these crimes and these atrocities you have committed." The multiple directions that a decision is capable of taking, and the many directions it can consequently travel, is introduced into the historical narrative; judgment on the guilty party is supplemented with the historiographer's admission that writing of the crime without reservation is just as important as keeping alive the idea that human action is contingent and that history is thus aleatory, thus producing, in the act of writing, a way of judging the past according to an ethical mandate--that human beings are capable of some good--made possible only by imagining what could have been, by uniting historiography with aesthetic practice.

In But for the Lovers, however, Rey exhibits no such forgiveness, for himself or for his characters. No one is let off the hook for either his or her foolishness or savageness. Again, Rey's self-described blasphemy remains rather vague, but it does seem to be directed at everyone he considers to have betrayed his dream of independence, whether Filipino, Japanese, or American. The reader, enjoined to the kinds of judgment Rey delivers upon his characters and himself, is in the position of either accepting Rey's assessment or of rejecting it, at least in its tone. Was Rey too hopeful? Were his hopes misguided? Or were they well-founded and understandable? There is of course no way to generalize what any reader may think of Rey or his characters. But it is possible to argue that But for the Lovers, given the kind of narrative that Rey has written, thematizes the very contingency by which the act of judgment itself must base its reasoning. When the reader is confronted with a narrative that presents a particular moment of history whose endpoint is already well-known, the reader, though guided through the events by the framework the writer establishes, is fully capable of reading against the grain and sympathizing with the characters in question. The fictional universe that Rey produces doubles back upon the work of historiography and turns the question of history's contingency into a matter of thinking through the unstable and unpredictable nature of reading, which includes the many different interpretations that a reader can give to a sequence of events. By calling attention to the reader in this way, But for the Lovers sends the capacity for forgiveness into an endless loop. She can say, against Rey, "I understand why you were so hopeful," and she can also say, "You are better than this, and you do not have to be so cruel in the way you write of yourself and of others." But she can also agree and think of Rey and his characters as fools. The contingency with which Ricoeur describes such an epistemological standpoint is possible only because the inner core of history remains present; there 
is a tacit understanding that such a forgiveness is even possible, that the perhaps foolhardy belief in a free Philippines can take hold as a contingency is sustainable, only because what seems inevitable and driven by necessity has already occurred. Rey's epilogue all but crushes the notion that anything else could have happened, and his sense of defeat acknowledges the very real presence of the Americans, regardless of how much one wishes otherwise. The imaginary force of forgiveness crashes into the concrete, which, paradoxically, authorizes the imagination to take flight away from such brute realities.

How Nolledo introduces contingency into his novel is in large part responsible for the way that Rey's epilogue acquires the force it has. It is no exaggeration to say that all readers of But for the Lovers are likely to know how the Second World War ended for the Philippines. The enormous cast of characters, however, seem to work in a way that holds in suspension that inevitability. Inside the small section of Manila featured by the narrative, the reader is introduced to around twenty characters who more or less have significant roles in the story. They are shown in relationships that flourish irrespective of hard political allegiances and are characterized instead by their malleability: enemies eat dinner together; the circuits of sexual desire, which move independently of politics, overflow until they can no longer be tolerated (whence the stoning of Maddalena, a transsexual dancer whose primary clients are the Japanese); contradictions in nationalist sentiment and ideology (like that of Deogracias) are held in abeyance as characters from all political persuasions meet and chat about both significant and mundane things. The specific emplotment that occurs here establishes a sequence of these kinds of flows until the unavoidable endpoint: the coming of the Americans and the largescale destruction it wrought. Such a narrative, which accounts for the breadth of styles and voices that comprise the novel's texture, so to speak, creates a sense of spaciousness, in which the intimate both undercuts and contours the much larger collective moments, such as the destruction of Tondo or the arrival of the Americans on Leyte. This intimate yet spacious memory creates a different type of epistemology, the "privilege of interiority" in which memory, as Ricoeur suggests, becomes the place where bearing witness to the grand narratives is born (Ricoeur 98). But the collective returns in full force in the epilogue to ratify what the reader already knows: that the Americans returned and that the suspensions of political allegiances and the many dreams of freedom, in whatever guise, that the reader became privy to throughout the course of the novel are doomed to the same fate: to burn in the flames lit by the Japanese as they retreated beneath the bombs dropped by American warplanes, or like Rey to dry up in a US Army base and left to fester. When Rey's epilogue appears, then, it explodes the tension that was there in the narrative all along: the multiple drives toward some future marked by sexual desire, lust, political dreams, and nostalgia run up against the common knowledge of the triumph of the American empire.

Kritika Kultura 24 (2015): -178

(C) Ateneo de Manila University

<http://kritikakultura.ateneo.net> 
There are thus two types of collectivity to be found in But for the Lovers. On the one hand, there is the collectivity represented by the cast of characters themselves, the kind of collectivity established by the spaciousness and privilege of interiority, in which all kinds of people are allowed to thrive or, quite simply, to live together, with the enmities of war momentarily set aside (though they are always there, in the background). On the other hand, there is the implied collectivity held together through the figure of the reader herself; the endpoint signaled by the epilogue, the trajectory that the novel had been moving toward all along, structures the novel according to the inevitability of this collective understanding of the Second World War's end. Here, in Nolledo's novel, the relationship between fiction and history does not cohere in the way that Hayden White describes their intimacy, where a given plot structure serves an historical interpretation in order to frame it according to a particular trope, whether tragic, comedic, or romantic ("Interpretation in History" 58). For what White's theories rely upon is a kind of historiography built upon the interpretation of an historical sequence like the French Revolution, or even the Philippine one (as the examples of Amado Guerrero and Renato Constantino show); what is at stake in these cases is how the historian contours the narrative through a particular interrogation of temporality itself, and the way that it structures and formalizes the events in question ("The Metaphysics in Narrativity" 180). In Nolledo's novel, however, Rey's epilogue links him not so much to the historiographer in this sense but quite explicitly to the fiction writer who is concerned with establishing the interior spaces of the personal domain as a dialectical counterpoint to the collective understanding establishable by the reader, to the fact of the American return, which is not open to interpretation. The way that Rey presents it is direct and forthcoming; what interpretation could have occurred in the novel, that is, the events that he has assembled as a series of "Dickensian notes" written in an "ornate vernacular," are exposed as fictions and nothing more. In addition to Rey's claim that the novel is his way of linguistically and metaphorically sheltering Alma (his symbol for the Philippines), there is no way that he could have witnessed the majority of the events depicted in the novel. These events are less instances where the historiographer attempts to interpret the past and more the occasions for a fiction writer's outright creation or, at the very least, literary embellishment.

The dialectic that structures But for the Lovers, then, is that between the contingencies represented by the personal and fictional, and the non-contingent signaled by the novel's structural trajectory and by its tacit appeal to the reader's knowledge of the American return. It is therefore possible to interpret Nolledo's novel and its density and style as a thematic counterpart to the kinds of work on memory and epistemology that Ricoeur has produced. The hermeneutic called for would thenceforth require speculation on the way that But for the Lovers' style calls attention and thematizes the kinds of "excesses" that Hau describes when talking about the heuristic necessity to establish the fiction of homogeneity and unity

Kritika Kultura 24 (2015): -178 
when formulating the question of Philippine nationalist and diasporic politics. For $\mathrm{Hau}$, art and literature give rise to interpretive communities that are capable of "undoing" these formulations and making such excesses-which include minority and subaltern populations-visible and articulable (Hau 117). The excesses of the postmodern Filipino novel in English may require a kind of "hermeneutic of excess" in order to properly historicize it and to see what these excesses have to say about the contradictions of a cultural politics that attempts to deal with the multiplicity of peoples, a plurality that cannot be denied. According to this perspective, the very problem of the nation, seen as an historically incomplete project, is a multiplicity spread out spatially and interrupted constantly throughout time. This is the history of the present that such a hermeneutic would have to account for as it struggles with whether or not literature is at all capable of providing some sort of epistemological foundation for thinking of the political, where some semblance of a collective memory and knowledge is nonetheless necessary in order to construct "an order of life in common," one built upon certain shareable notions and histories (Ricoeur 130).

And yet, this is not enough. One thing that I have yet to address, but which I have mentioned already, is the fact that Placido Rey, in elaborating his fiction, kills every single one of his characters off. With the exception of Amoran, Alma, and himself, every figure in his narrative meets some sort of grisly end. Maybe this is the true source of Rey's blasphemy. But to repeat-against what? The sanctified notion of the people, of his people, of human dignity? Maybe. It could be all these things. But since the novel gives no clues, we are left at a dead end here. What is more important is that Rey's fictionalization, and the realm of personal memory that it calls attention to as it confronts the reader's knowledge of empirical history, is also the occasion for a mass, though fictional, killing. Eliminating an entire cast of characters as a mark of resignation becomes, here, a horrifying symptom of Rey's frustration at the recent past. In the novel, the domain of contingency is also the site of a massacre; Rey kills everyone off and in a surprising reversal of logic, the collectivity established by the spacious realm in which interpersonal relationships occur irrespective of political and national allegiances, where the war itself is momentarily suspended, is also the collectivity that Rey targets for annihilation. And as the writer, as the one who is capable of imagining their fates and introducing into their lives every possibility conceivable, he has them meet their ends--some of them gradually, over the course of the novel, but many of them in the final conflagration, as Tondo is wiped out by fire, as lives are ended in hails of bullets and under collapsing buildings.

What can be said about how fiction relates to the killing off of so many lives? What can be said of the relationship between the imaginary realm and mass murder, and what it might have to do with memory and history? What follows is the most speculative portion of this essay, and will consequently serve as a series of propositions for future research. It can be summed up, however, by a single

Kritika Kultura 24 (2015): -178 
provocation: that what underwrites Nolledo's novel, and what may be the horizon for a literary hermeneutic of postmodern Philippine novels in English-and perhaps all Philippine novels in English-is the scholar's and critic's confrontation of a history of genocide. Specifically, it is the history of the United States' westward expansion that must be dealt with. From this standpoint, the Second World War was merely one moment along a continuum that witnesses the US' consolidation of the Philippines as its most remote, Pacific outpost on its centuries-long imperial journey. As Dylan Rodriguez argues, "Manifest Destiny, in its transpacific articulation, fully advanced the well-worn program of land alienation and cultural genocide" (132) that drove on its takeover of indigenous lands, of its push toward Hawaii and the Philippines, where the logic became firmly entrenched as an overseas extension of the policies toward Native Americans on the continent (121-122). That the numbers of just how many Filipinos were killed during the campaigns of 1900-1901 (which is a topic of debate ignited by Gore Vidal in his 1981 essay, "Death in the Philippines"), makes it all the more necessary to revisit this moment, since the manner of its presentation, and the archival work necessary to disclose the ethos of the United States' nationbuilding project, is a matter not limited to the work of archival research alone: it is also a matter of writing, of how to present and contour this narrative. This is the kind of historiography that Paul Ricoeur and Hayden White devoted their research to, and it is to their intellectual legacies that we must include fiction in this problem of how to confront and think of history through writing. This directs research toward the asking how a literary hermeneutic is to respond to literature as one component in a vast field of historiographical practices. If Ricoeur is right in arguing that how one comports oneself to a heritage is an indispensible part of constructing history, and that it is to this heritage that one owes a debt-to be indebted to those who have come before us-then the question of writing genocide is crucial for understanding the tensions between literature, history, and any conceivable politics of literature. The kind of recollection possible through the contingencies of the fictional and imaginative realm is where some of the "moral priority" shouldered by the one who remembers lies: and it is to the victim, Ricoeur says, that the debt of memory must be paid. What is at stake here is how to see the victim as the other, the one "other than ourselves" (89). The victim is not the one who remembers; it is not the one who writes, but is instead the object of study, the subject of the narrative, to whom the writer must call attention and with whom she must proclaim solidarity without making the mistake of declaring that they are in any way-and could in any way-be one and the same. The presence of the victim in a discourse, in Ricoeur's assessment, implies a collectivity already: the self and an other, a collectivity of great exigency, since if the self is duty-bound to this other, recollecting and representing the crime is a moral and political obligation for the writer.

Kritika Kultura 24 (2015): -178

(C) Ateneo de Manila University

<http://kritikakultura.ateneo.net> 
For the literary critic concerned with Anglophone writing from the Philippines, what I have been calling postmodern Filipino novels in English, though this may extend outwards to many other fields of study to include Anglophone writing done from the peripheries and at the very heart of the American empire, the obligation is this: to recognize the political horizon that is genocide. When the history of Manifest Destiny comes into view, the obligation involves representing the heritage bequeathed by genocide, to keep doing the work that would involve the writer to comport herself toward the history of political mass murder. To be sure, the killings in But for the Lovers do not constitute genocide per se; the mass killings occur irrespective of nationality, culture, or race. It is both genocide and not; it is a radicalization of it, which is why it is curious that such killings occur in the first place. Can the large-scale destruction that occurs just prior to the epilogue be defined as an apocalypse, the final annihilation toward which the novel was headed all along and through which it was structured? This is possible. If one were indeed to orient oneself toward genocide as a horizon for thought, if one were to establish a literary hermeneutic where the ambit for criticism places the political and economic dimensions of imperialism and Manifest Destiny from within the overarching logic of genocide, then it is possible. Rey's apocalypse becomes from this standpoint the twin vector of a destruction that places it squarely-and fictively-in the same historical moment as the Americans' return: the second coming of the US is indeed an annihilation, an association that Rey's narrative helps to create. Rey seems to be saying, "If the Americans return, then so will widespread destruction, so will apocalypse." The conflagrations of the Second World War, as they swept across the Philippines, must be seen as one moment in the century-long process of America's "experiment," as it is sometimes called, in the country. The strafing that the Pacific received during the war must be read against the backdrop of America's incursions in the late nineteenth and early twentieth centuries, without which the history of this region, and the history of the United States itself, from World War 2 and on, is unintelligible. There is of course no room to argue these points. These are for future studies to deal with, and must be left in their hypothetical form.

Nonetheless, this is one way to tackle the issue of the modes of narration that But for the Lovers employs. If the novel's greatest tension lies in the way that the contingencies marked out by the body of the main narrative run against the sense of inevitability inscribed by the epilogue, then the hermeneutic I have been alluding to this entire essay would have to orient itself toward the following conclusion: that the epilogue suggests that it is impossible to imagine history otherwise. This is the devastating coda to the sense of freedom and wildness imbued throughout much of the novel's excessive verbiage. This is because imagining history against itself means imagining against the history of mass killings, of brutality, of cruelty, of genocide, and finally of America's return to the Philippines, of the continuum that treating this moment of history as such can help to establish between the so-called "war" between the two countries up to World War 2 and to the close relationship

Kritika Kultura 24 (2015): -178 
maintained between the two in the twenty-first century. In the case of But for the Lovers, this entire history is written into the very structure of the novel itself, and if this history is the horizon for any literary hermeneutic, it is because this hermeneutic must recognize that beyond it the text cannot be legible and cannot properly speaking be said to exist at all.

The style of Butfor the Lovers, then, can be read as a function of the postmodern moment-and not necessarily as its unwitting or even willing collaborator. If But for the Lovers does not answer the riddle of the Philippines' future, if it remains reticent about the diaspora and if it cannot properly solve the problem of what it means to read a difficult text, it is not because it suffers from the afflictions of postmodernism. Rather, it is because the novel cannot-as a novel-answer the question of the nation and must indeed leave it suspended: what the critic and scholar must orient her thinking toward is the way that the novel constantly inscribes the horizon of genocide into its very structure and form, one in which the problem of the nation, of the postcolonial nation, remains unable to solve for itself, either in history or at the present moment. What literature can do, such a hermeneutic would say, is to show in what way literary form is capable of giving rise to an epistemology of these unsolved problems, of giving form to a thought on the contradictions between the poetic imagination and the political as it attempts to confront the history of how collectivities have both been formed and destroyed, and what it means to fictionalize and remember these lives and deaths now.

If the complaint is that postmodern literature is too in love with itself to look beyond its own textuality, then a new literary hermeneutic would say this: that it is the job of the literary scholar and critic to place herself within the tensions of literature's perhaps increased autonomy (intensified by postmodernity) and the historical. This is where the poetic imagination's freedoms confront the brute facts of the real, the very conflict that But for the Lovers formalizes and dramatizes. The reader's freedom to judge is met with the harshness of what history forces us to face. The collective memory-shaped by research done alongside and not independently of research into literature-makes the problem of reading, of the literary hermeneutic the outlines for which I have been developing here, into a moment of possible collective judgment against a crime like genocide, and the nation-building project it helped to support. Following Ricoeur, this collective judgment against history is collective precisely because it orients itself toward the victim, the other of the self, the other of the scholar, the critic, and the reader. Such a perspective throws some new light on the question of literary style, then: with genocide underwriting the very condition that makes the history of the United States throughout the twentieth century (and even before that, through the three hundred preceding years during which a majority of the indigenous populations across the continent were wiped out) newly intelligible, the very "Englishness" and "postmodern-ness" in the phrase postmodern Filipino novel in English are also clarified just a little more. They begin to be seen as outcomes of an historical

Kritika Kultura 24 (2015): -178 
and political trajectory shaped by American hegemony over the course of the last century. There are no answers here, no solutions; what is left are the distortions that ripple in the wake of history's barbarities. It is the literary scholar and critic's job to decide what shape these ripples take in the imagination, in the realms where fabulation meets political and ethical judgment, and what these ripples--these traces of a past violence--may say about the unseen depths and the vastness that surround them. 


\section{Notes}

1. See, for instance, Adam David, "Pity Not the Elite but Condemn Them All." http://wasaaak.blogspot.com/2009/o3/pity-not-elite-but-do-not-condemnthem.html, accessed Dec. 19, 2014. See also Marya Salamat, "In Ilustrado and Eight Lives Lived, Which Life is Worth Writing About?" http://bulatlat.com/ main/2010/09/25/book-review-in-ilustrado-and-eight-lives-lived-which-lifeis-worth-writing-about/, accessed Dec. 19, 2014.

2. See especially The Condition of Postmodernity: An Enquiry into the Conditions of Cultural Change (Cambridge: Wiley-Blackwell, 1992), 141-200, 327-359.

3. See, for instance, his chapter on Carlos Bulosan, "Revisiting Carlos Bulosan," in Toward Filipino Self-Determination: Beyond Transnational Globalization, 74.

4. Fredric Jameson, Marxism and Form (Princeton: Princeton UP, 1971), 348-416; and The Political Unconscious: Narrative as a Socially Symbolic Act (Ithaca: Cornell UP, 1981), 117-119, 144, 148, 183-184, 217-218. 


\section{Works Cited}

Adorno, Theodor. Aesthetic Theory. Trans. Robert Hullot-Kentor. Minneapolis: University of Minnesota, 1998. Print.

Habermas, Jürgen. "Modernity-An Incomplete Project." Trans. Seyla Benhabib. New German Critique 22 (1981). Online. 19 Dec. 2104.

Hau, Caroline. Necessary Fictions: Philippine Literature and the Nation, 1946-1980. Quezon City: Ateneo de Manila UP, 200o. Print.

Jameson, Fredric. Marxism and Form. Princeton: Princeton UP, 1971. Print.

--. The Political Unconscious: On Literature as a Socially Symbolic Act. Ithaca: Cornell UP, 1982. Print.

--. Postmodernism; or, The Cultural Logic of Late Capitalism. Durham: Duke UP, 2003. Print.

Lim, Jaime. Literature and Politics: The Colonial Experience in the Philippine Novel. Indiana U, 1989. Dissertation. Web. 19 Dec. 2014.

Lyotard, Jean-François. The Postmodern Condition: A Report on Knowledge. Trans. Geoff Bennington and Brian Massumi. Minneapolis: U of Minnesota P, 1994. Print.

Nolledo, Wilfrido. But for the Lovers. Normal: Dalkey Archive, 1994. Print.

Ranciére, Jacques. The Politics of Aesthetics. Trans. Gabriel Rockhill. New York: Bloomsbury, 2006. Print.

Ricoeur, Paul. Memory, History, Forgetting. Trans. Kathleen Blamey and David Pellauer. Chicago: $U$ of Chicago P, 2006. Print.

Rodriguez, Dylan. Suspended Apocalypse: White Supremacy, Genocide, and the Filipino Condition. Minneapolis: U of Minnesota P, 2009. Print.

San Juan, Epifanio, Jr. "Filipino Writing in the United States: Reclaiming Whose America?" Philippine Studies 41.2 (1993): 141-166. Web. 20 Dec. 2014.

--. Toward Filipino Self-Determination: Beyond Transnational Globalization. Albany: State U of New York P, 2009. Web. 20 Dec. 2014.

Teodoro, Luis V. “Toward the Insurgent Seventies." Two Perspectives on Philippine Literature and Society. Ed. Belinda A. Aquino. Philippine Studies Occasional Paper No. 4. Philippine Studies Program, Center for Asian and Pacific Studies, U of Hawaii. January 1981. Web. 5 Feb. 2015.

White, Hayden. "Interpretation in History." Tropics of Discourse: Essays in Cultural Criticism. Baltimore: Johns Hopkins UP, 1978. 51-8o. Print.

--. “The Metaphysics of Narrativity: Time and Symbol in Paul Ricoeur's Philosophy of History." The Content of Form: Narrative Discourse and Historical Representation. Baltimore: Johns Hopkins UP, 1990. 169-184. Print. 